\title{
The Consumption of Mineral Fertilizers and Herbicides in Poland Against the Background of the European Union ${ }^{2}$
}

\begin{abstract}
The popularity of fertilizers and plant protection treatments with chemical preparations is based, among other factors, on their ease of use and fast effects. This paper presents an analysis of the consumption of selected agrochemicals in EU-28 agriculture in type and spatial arrangement. The main aim of the article is to present changes in the examined scope, including the identification of Poland's rank in the consumption of selected agrochemicals against the background of European Union countries. According to the analysis, the consumption of mineral fertilizers and herbicides in Poland is one of the highest in Europe. Due to potential threats to human health and life and environmental risks, special attention should be paid to agricultural practices with regard to the use of agrochemicals.
\end{abstract}

Key words: low carbon agriculture, mineral fertilizers, plant protection products, Poland

JEL Classification: Q12, Q19, Q50

\section{Introduction}

Agrochemicals, i.e. preparations and chemicals used in agriculture as agricultural inputs, are an important factor in the development of agribusiness. Chemical products that have found a wide application in agriculture include mineral fertilizers and pesticides. Chemical products also play an important role in animal production (e.g. feed additives, veterinary drugs). Mineral fertilizers contain elements necessary for proper growth and development of crops. The use of fertilizers containing macronutrients and micronutrients is currently an indispensable element of commodity agriculture. Pesticides, on the other hand, are often the most effective, fast-acting and convenient products to use against various pests (Lamichhane et al., 2016). The use of agrochemicals in plant production, in addition to the yield creative and yield-protective effects, is linked to threats to human life and health and to pressure on the natural environment (Makles, Domański, 2008; Böcker, Finger, 2016; Schütte et al., 2017; Islam et al., 2018). From this point of view, it is extremely important to monitor their presence (e.g. in the soil and water environments and in food).

Important from the cognitive point of view, including the idea of sustainable development of agriculture and rural areas, is the analysis of the consumption of agrochemicals at different levels of spatial management (Piwowar, 2018). This article presents analyses on the consumption of basic agrochemicals in EU-28 countries. Two product groups were identified for the analysis: mineral fertilizers and herbicides. The

${ }^{1}$ PhD Eng., Department of Economics and Organization of Food Economy WUE, ul. Komandorska 118/120, 53-345 Wrocław, e-mail: arkadiusz.piwowar@ue.wroc.pl; https://orcid.org/0000-0001-5676-9431

${ }^{2}$ Article funded by the National Science Centre from the funds for science within research project in the field of basic research - Sonata No. 2016/21/D/HS4/00087, entitled "The state and prospects of the development of lowcarbon agriculture in Poland and the behaviour of agricultural producers". 
policy debates on plant protection products (PPPs) in the European Union (EU) are actually dominated by the environmental implications of crop protection (especially the use of herbicides) (Bonanno et al., 2017). The main aim of the article is to present changes in the volume and structure, including the identification of Poland's position in the consumption of selected agrochemicals against the background of European Union countries. The basic time scale of the analysis covered the years 2011-2014.

\section{Consumption of mineral fertilizers and herbicides in the European Union}

Crops require a sufficient amount of nutrients for correct growth, development and high yields. In addition to macroelements (nitrogen, phosphorus, potassium, sulphur and magnesium), which the plants absorb in relatively large quantities, microelements (e.g. boron, copper, iron) are also important. It is worth pointing out that the quantitative demand for nutrients depends on the species and even the varieties of plants. As a result of the "nutrient take-away" with plant yields, reduced organic fertilization, and changes in the market of agricultural seeds, commercial agriculture is required to supplement nutrients in the form of mineral fertilization. The chemical industry offers a varied assortment of mineral fertilizers, including single, double and multi-component fertilizers in solid and liquid form (Piwowar, 2012).

Table 1. Size and structure of mineral fertilizer consumption in selected EU-28 countries in 2011-2014

\begin{tabular}{l|ccc|ccc}
\hline \multirow{3}{*}{ Specification } & \multicolumn{7}{c}{ Fertilizer consumption } \\
\cline { 2 - 6 } & \multicolumn{7}{|c}{ [thous. tonnes NPK] } & \multicolumn{4}{c}{ [\%] } \\
& $2011 / 2012$ & $2012 / 2013$ & $2013 / 2014$ & $2011 / 2012$ & $2012 / 2013$ & $2013 / 2014$ \\
\hline France & 2915 & 3079 & 3093 & 19 & 19 & 18 \\
Germany & 2273 & 2354 & 2416 & 15 & 14 & 14 \\
Poland & 1884 & 1943 & 1935 & 12 & 12 & 12 \\
Spain & 1350 & 1677 & 1739 & 9 & 10 & 10 \\
United Kingdom & 1448 & 1469 & 1544 & 9 & 9 & 9 \\
Italy & 875 & 894 & 903 & 6 & 5 & 5 \\
Romania & 671 & 646 & 707 & 4 & 4 & 4 \\
Ireland & 471 & 524 & 543 & 3 & 3 & 3 \\
Hungary & 404 & 452 & 460 & 3 & 3 & 3 \\
Czech Republic & 388 & 371 & 444 & 3 & 2 & 3 \\
UE-28 & 15375 & 16341 & 16788 & 100 & 100 & 100 \\
\hline
\end{tabular}

Source: (Zalewski 2016), author's own elaboration.

High efficiency of mineral fertilization has contributed to the spread of mineral fertilizers all over the world. For example, the global consumption of mineral fertilizers in $1905 / 1906$ was 1.9 million tons of NPK, in 1992/1993 it had increased to 125.9 million tons of NPK, and in the years 2013/2014 it amounted to 180.7 million tons of NPK (Zalewski, 2009). It is worth pointing out that the consumption of mineral fertilizers in the EU-28 in year 2013/2014 accounted for $9.3 \%$ of global consumption (Zalewski, 2016). 
The size and structure of mineral fertilizer consumption in selected EU-28 countries in the years 20112014 is presented in Table 1.

The consumption of mineral fertilizers in the EU-28, in the period under review, increased by 1.4 million tons of NPK. In the geographic structure of mineral fertilizer consumption in the EU-28 countries, France, Germany and Poland have the largest share. Of these countries, the highest rate of change in fertilizer consumption over the period considered was recorded in Spain (by 28.8\%), Ireland (by 15.3\%), the Czech Republic (by $14.4 \%$ ) and Hungary (by $13.8 \%$ ). The amount of fertilizers used, shown in Table 1, is determined by the resources of agricultural land and the structure of sowing in individual countries. In order to compare the levels of mineral fertilizers used, in agricultural economics the unit consumption index per area unit $(\mathrm{kg} / \mathrm{ha} \mathrm{AL})$ is used. The level of fertilization in selected ${ }^{3}$ EU-28 countries is presented in Figure 1.

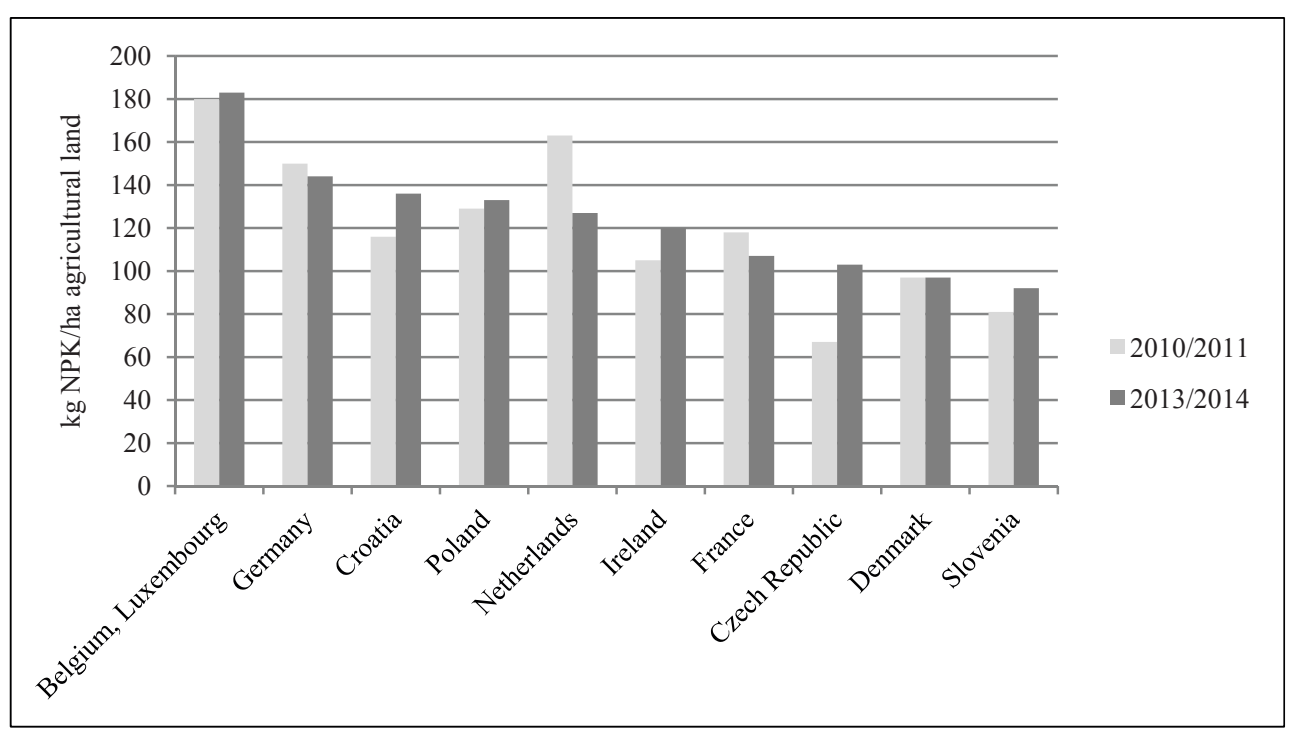

Fig. 1. Fertilization level in selected EU-28 countries

Source: Source: (Zalewski 2016), author's own elaboration.

The highest unitary levels of mineral fertilizers in years 2013/2014 were recorded in Belgium and Luxembourg (183 kg NPK/ha AL), Germany (144 kg/ha AL), Croatia (136 kg $\mathrm{NPK} / \mathrm{ha} \mathrm{AL}$ ) and Poland (136 kg NPK/ha AL). What is worth emphasizing, is the significant decrease in fertilization in the Netherlands and the increase in fertilization in the Czech Republic (in both cases, by $36 \mathrm{~kg} \mathrm{NPK} / \mathrm{ha} \mathrm{AL}$ ). High growth in unit consumption of fertilizers has also been reported in Croatia, Ireland and Slovenia. The structure of fertilizer use in selected EU-28 countries is presented in Table 2.

Nitrogen fertilizers dominated the structure of mineral fertilization in each of the studied countries. It is worth noting that the intensification of fertilization can be related to increased penetration of soluble components, especially nitrogen, into the aquatic

\footnotetext{
${ }^{3}$ As in the previous analyses, 10 countries with the largest volume of fertilizer consumption were selected.
} 
environment. In the 2013/2014 year in the Netherlands and the Czech Republic, nitrogen fertilizers accounted for $83 \%$ of total fertilization. There is significant regional differentiation in terms of amounts and share of phosphate fertilizers in the structure of the investigated phenomena. Among the countries listed in Table 1, the highest unit consumption of phosphate fertilizers in the 2013/2014 business year was recorded in Poland (23 kg/ha AL), while the consumption of potassium fertilizers was highest in Belgium and Luxemburg (37 kg/ha AL) and Poland (34 kg/ha AL). According to Matyka (2013) and Tarnowska (2016), strong increased consumption of mineral fertilizers in Poland has been recorded since accession to the European Union. In the balanced fertilization of field crops under the soil conditions occurring in Poland, the following NPK fertilization proportions are recommended: 1.00:0.50:0.98 (in the case of permanent grassland: 1.00: 0.46: 0.68).

Table 2. Structure of fertilizer consumption in selected EU-28 countries

\begin{tabular}{l|cc|cc|cc}
\hline \multirow{2}{*}{ Specification } & \multicolumn{5}{c}{ Mineral fertilizer consumption [\%] } \\
\cline { 2 - 6 } & \multicolumn{2}{|c}{ nitrogenous } & \multicolumn{2}{c}{ phosphorous } & \multicolumn{2}{c}{ potassium } \\
& $2010 / 2011$ & $2013 / 2014$ & $2010 / 2011$ & $2013 / 2014$ & $2010 / 2011$ & $2013 / 2014$ \\
\hline Belgium, Luxembourg & 72 & 71 & 8 & 9 & 20 & 20 \\
Germany & 71 & 69 & 11 & 12 & 17 & 19 \\
Croatia & 62 & 71 & 16 & 13 & 22 & 16 \\
Poland & 56 & 57 & 21 & 17 & 23 & 26 \\
Netherlands & 79 & 83 & 8 & 7 & 13 & 9 \\
Ireland & 73 & 63 & 10 & 16 & 17 & 21 \\
France & 68 & 71 & 14 & 15 & 18 & 14 \\
Czech Republic & 67 & 83 & 10 & 9 & 22 & 8 \\
Denmark & 77 & 76 & 5 & 5 & 18 & 19 \\
Slovenia & 48 & 57 & 21 & 21 & 31 & 23 \\
UE-28 & 67 & 68 & 15 & 16 & 17 & 17 \\
\hline
\end{tabular}

Source: (Zalewski 2016), author's own elaboration.

Large amounts of chemical plant protection products are used in EU agriculture. It is a group of production means of yield-protective importance and it includes, among others, herbicides (plant protection products intended for the control of undesirable weeds in crops). Weed control is effected by the active (biologically active) substance contained in the herbicides, which enters the plants (through leaves or roots) and spreads throughout the conductive system, disrupting the vital processes (Grygiel et al., 2012). In industrial agriculture, herbicides are used on a large scale. Herbicides are also used in forestry (Flueck, Smith-Flueck, 2006; Vasic et al., 2015) as well as in built-up and urbanized areas.

Market data regarding pesticide management shows sales figures for each country. The concept of plant protection product sales and the use of plant protection products are not identical, but given the fact that most of the purchased products are used directly after purchase and that there are laws restricting the movement of these products, it can be assumed that pesticides sold in a given country will also be used in it (Matyjaszczyk, 2014). 
Data on the volume and sales structure of herbicides in selected ${ }^{4} \mathrm{EU}$ countries are presented in Table 3.

Table 3. Sales of herbicides in selected EU-28 countries in 2011-2014

\begin{tabular}{|c|c|c|c|c|c|c|c|c|}
\hline \multirow{3}{*}{ Specification } & \multicolumn{8}{|c|}{ Sales of herbicides } \\
\hline & 2011 & 2012 & 2013 & 2014 & 2011 & 2012 & 2013 & 2014 \\
\hline & \multicolumn{4}{|c|}{ [thous. tonnes of active substances] } & \multicolumn{4}{|c|}{$[\%]$} \\
\hline France & 29 & 28 & 28 & 31 & 22 & 21 & 22 & 25 \\
\hline Germany & 18 & 20 & 18 & 18 & 13 & 15 & 14 & 14 \\
\hline Spain & 14 & 14 & 15 & 15 & 10 & 10 & 11 & 12 \\
\hline United Kingdom & 12 & 11 & 10 & 12 & 9 & 8 & 8 & 10 \\
\hline Poland & 12 & 13 & 13 & 12 & 9 & 9 & 10 & 10 \\
\hline Italy & 8 & 8 & 7 & 8 & 6 & 6 & 6 & 6 \\
\hline Romania & 7 & 7 & 6 & 5 & 5 & 5 & 5 & 4 \\
\hline Hungary & 4 & 4 & 4 & 4 & 3 & 3 & 3 & 3 \\
\hline Netherlands & 3 & 3 & 3 & 3 & 2 & 2 & 2 & 3 \\
\hline Czech Republic & 3 & 4 & 3 & 3 & 3 & 3 & 2 & 2 \\
\hline EU-28 & 134 & 135 & 128 & 126 & 100 & 100 & 100 & 100 \\
\hline
\end{tabular}

Source: author's own study based on Eurostat data (http://ec.europa.eu/eurostat).

Taking into account the EU herbicide market, the largest volume of sales is recorded in France (in 2014 the volume of sales was 31 thous. tonnes of active substance, i.e. $25 \%$ of total amount in EU-28). In terms of sales volume, Poland was ranked 5th in the EU in 2014 (12.7 thous. tonnes of herbicide sales), after France, Germany, Spain and Great Britain. For comparison of sales volume of pesticides, the conversion factor per unit area was used (Figure 2).

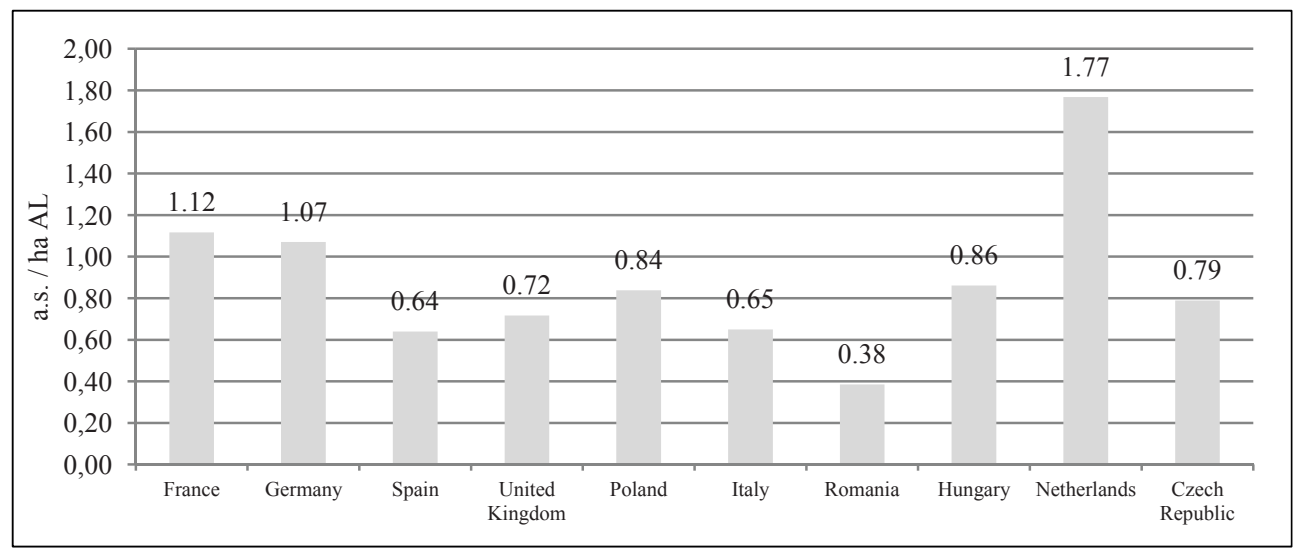

Fig. 2. Sales volume index of herbicides in selected EU-28 countries in 2014

Source: author's own study based on Eurostat data (http://ec.europa.eu/eurostat).

\footnotetext{
${ }^{4}$ Top 10 countries with the highest sales of herbicides in the EU-28 (in total commodities).
} 
Comparison of the unit consumption index of herbicides in selected countries shows differences in intensity of use of these agrochemicals. According to the analysis, the herbicide sales volume index was the highest in the Netherlands $(1.77 \mathrm{~kg}$ a.s. /ha AL). The index calculated for Poland in the analogous period was $0.84 \mathrm{~kg}$ a.s./.ha AL, which classified Poland in 5th place in the group of 10 countries with the highest sales of herbicides in EU-28 (in bulk). However, attention should be paid to the generality of the measure used, as the active substances which are part of preparations for weeding treatments are highly diversified. Diversification of the active ingredient also results in differentiation of dosages, which does not allow easy capture of the detailed differences by using a general measure of consumption as the mass of all active substances per unit area. Unfortunately, particulars on the consumption of individual substances are not available. Statistics also do not show the number of plant protection treatments performed (Urban 2007). However, available statistical data clearly indicate a steady increase in sales of plant protection products in Poland (Malinowska et al., 2015). In Polish statistical sources has only incidental data available regarding the diversification in the number of agrochemical treatments in agriculture. The publication entitled "Means of production in agriculture in the 2014/2015 farming year" (GUS 2017), issued by the Central Statistical Office (GUS), provides information on the spatial diversity (in terms of provinces) in the number of agricultural holdings in Poland which conduct plant protection treatments and in the number of treatments performed in cereal crops, vegetable crops, permanent crops and other crops. Because the temporal scope of these analyses covers the years 2015/2016, these results are not presented in this study (temporal scope until 2014).

\section{Changes in the consumption of agrochemicals in Polish agriculture in the context of market and legal conditions}

The trend of changes in the consumption of selected agrochemicals in Poland in the context of market and legal transformations are significant for the objectives of this paper. Figure 3 shows selected concepts, methods and techniques that determine changes in the use of agrochemicals in agriculture.

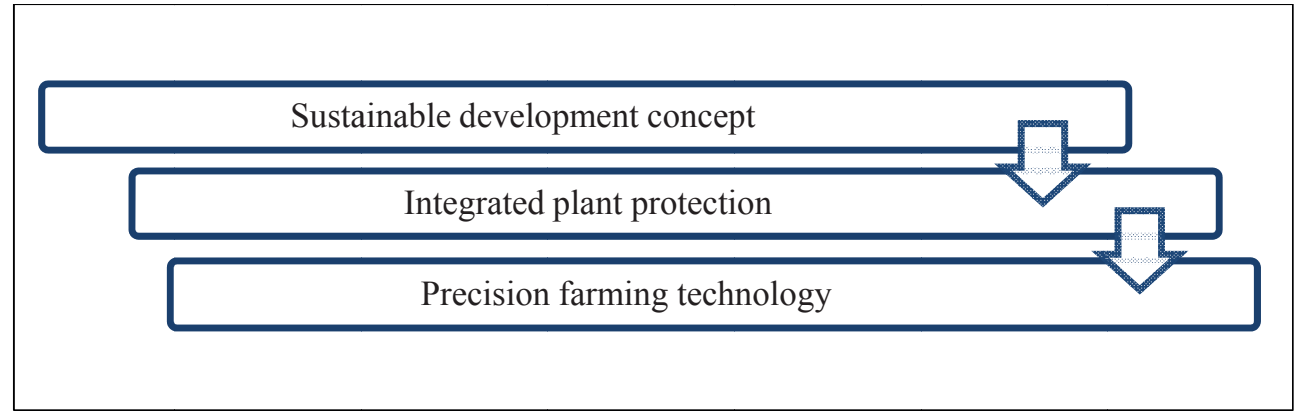

Fig. 3. Selected concepts, methods and techniques that determine changes in the use of agrochemicals in agriculture

Source: author's own elaboration. 
An important element in the concept of sustainable development, as a priority for social development, including sustainable development of agriculture, is the reduction or elimination of threats to the natural environment. What really matters in this context, is rational fertilizer and pesticide economy, reducing the negative impact of the environmental pressures associated with the use of agrochemicals. Achieving this state requires a number of activities at the microeconomic level (on farms), resulting from adopted strategies, management methods and techniques. Substantial in this respect are the changes made in law. An example of changes affecting agricultural practices in the field of pesticides is the obligation to apply the principles of integrated plant protection. Since January 1, 2014 there is a legal obligation in Poland to apply the general principles of integrated plant protection by all professional users of plant protection products. Integrated plant protection comes from the idea of sustainable development and is based on several basic principles. First and foremost, it reduces the use of chemical plant protection products to the necessary minimum, giving other methods priority over chemical protection. The basis of plant protection is monitoring and taking into account the thresholds of economic risk. Prevention and the use of decision support systems are both important. In turn, balanced fertilization, based on regulated soil reaction, plant nutrient requirements and soil fertility, become an important part of Good Agricultural Practice (GAP).

In order to ensure sustainable development of agriculture in Poland, it is necessary to introduce system changes that will facilitate the implementation and dissemination of innovations in the scope of agrochemicals, which will also increase the level of ecological knowledge and awareness among agricultural producers. A condition for long-term sustainability in the development of Polish agriculture in the scope of agrochemicals is smart growth based on knowledge, innovation and establishment of partnerships for sustainable development (between producers, distributors of means of agricultural production and farmers). Introduction of new technologies and techniques in the investigated area will help maintain the high quality of the natural environment and protect its resources (Piwowar, 2018).

Also, the instruments introduced under the Common Agricultural Policy can contribute to the realization of sustainable development in the field of fertilizers and pesticides. Within the framework of the current RDP 2014-2020 in agri-environment and climate-related actions, Package 1 - Sustainable Agriculture, was distinguished. The purpose of this package is prevention of organic matter loss in soil and rational use of fertilizers. The beneficiary implementing this package is obliged, for example, to carry out a soil analysis twice and to carry out an annual fertilization plan. Elements related to the rational economy of agrochemicals are also present in other packages, such as in Package 2 - Soil and Water Conservation, which is to promote agronomic practices against soil erosion, loss of organic matter and contamination of waters with soil-washed components.

As emphasized by Jarecki and Bobrecka-Jamro (2013), in recent years in Poland there have been major changes in the volume of deliveries, the assortment structure and the use and effects of agrochemicals. With regard to pesticides, the changes resulted from the reduction in the number and variety of registered plant protection products (in all EU Member States) (Matyjaszczyk, 2013). On the other hand, the changes in the market of mineral fertilizers are connected with the increasingly attractive products created by the chemical industry, regarding both soil and foliar fertilizers.

An important aspect of implementing sustainable development in the use of agrochemicals relates to the methods, techniques and tools of management within the farm. 
Knowledge and the ability to use decision support systems, implementation of precision farming techniques and tools (variable fertilization and plant protection treatments, combining sowing with fertilization) are of extreme importance to the studied subject. It is necessary to strengthen the knowledge and awareness among farmers, which is the responsibility of the education and agricultural counselling system.

\section{Conclusion}

Mineral fertilizers and herbicides play an important role in modern agriculture in Poland The level of consumption of these resources in the period examined in this study puts Poland among the highest users of these products in the EU-28. Although it is very often said that "Polish agriculture consumes relatively little chemistry", the level of mineral fertilization in Poland is next to Benelux, Germany and Croatia, the highest in the EU-28. In some regions of Poland (mainly in the South West Macroregion) the applied fertilizers exceed the average level of consumption in the countries with the highest level of fertilization in Europe. In general public opinion, agriculture in Poland uses also small doses of pesticides. It is worth emphasizing that Polish farmers use fewer total pesticides than their western European counterparts. The level of herbicides sales per hectare of agricultural land is lower in Poland than in the Netherlands, Germany and France, but higher than in Spain and Great Britain. In this context, with the currently high consumption of agrochemicals in Polish agriculture, one of the key issues is greater public activity and interdisciplinary cooperation in matters related to the sustainable use of agrochemicals. It is also necessary to develop agricultural knowledge and awareness in the field of nutrient management and plant protection at the farm level. Economic science should provide answers and support in this regard.

\section{References}

Bonanno, A., Materia, V.C., Venus, T., Wesseler, J. (2017). The Plant Protection Products (PPP) Sector in the European Union: A Special View on Herbicides. The European Journal of Development Research, 29(3), 575-595

Böcker, T., Finger, R. (2016). European pesticide tax schemes in comparison: an analysis of experiences and developments. Sustainability, 8(4), 378; doi:10.3390/su8040378.

Flueck, W.T., Smith-Flueck, J.A.M. (2006). Herbicides and Forest Biodiversity: An Alternative Perspective. Wildlife Society Bulletin 34(5), 1472-1478.

Grygiel K., Sadowski J., Snopczyński T., Wysocki A. (2012). Pozostałości herbicydów w płodach rolnych i glebie (Herbicide residues in agricultural products and in the soil). Journal of Ecology and Health, 16(4), 159-163. http://ec.europa.eu/eurostat.

Islam, F., Wang, J., Farooq, M.A., Khan, M.S., Xu, L., Zhu, J., Zhao, M., Muños, S., Li, Q.X., Zhou, W. (2017). Potential impact of the herbicide 2, 4-dichlorophenoxyacetic acid on human and ecosystems. Environment International, 111, 332-351.

Jarecki, W., Bobrecka-Jamro, D. (2013). Zużycie środków do produkcji rolniczej w Polsce w kontekście retardacji przemian rolniczej przestrzeni produkcyjnej (The consumption of basic production means in Polish agriculture in respect to sustainable development of agriculture and rural areas). Inżynieria Ekologiczna, 34, 121-128.

Lamichhane, J.R., Dachbrodt-Saaydeh, S. Kudsk, P. Messean, A. (2016). Toward a reduced reliance on conventional pesticides in European agriculture. Plant Disease, 100(1), 10-24; DOI 10.1094/PDIS-05-150574-FE http://prodinra.inra.fr/record/349675. 
Makles, Z., Domański, W. (2008). Ślady pestycydów - niebezpieczne dla człowieka i środowiska (Traces of pesticides - dangerous for human and for the environmental). Bezpieczeństwo Pracy, 1, 5-9.

Malinowska, E., Jankowski, K., Wyręek, H., Truba, M. (2015). Struktura sprzedaży i zużycia środków ochrony roślin w Polsce w latach 2000-2012 (Sale and use structure of plant protection products in Poland in the years 2000-2012). Zeszyty Naukowe Uniwersytetu Przyrodniczo-Humanistycznego w Siedlcach, 104, 173185 .

Matyjaszczyk, E. (2013). Wybrane problemy rolnictwa i obszarów wiejskich w kontekście zmian przepisów dotyczacych ochrony roślin w ostatnim dziesieccioleciu (Selected problems of rural areas and agriculture in light of legal changes regarding plant protection in the last decade). Roczniki Naukowe Ekonomii Rolnictwa i Rozwoju Obszarów Wiejskich, 100(3), 82-89.

Matyjaszczyk E. (2014). Rynek środków ochrony roślin w Polsce w 2012 r. w ujęciu ilościowym i wartościowym (Market of plant protection products in Poland in the year 2012 in terms of volume and value). Roczniki Naukowe SERiA, 16(3), 177-182.

Matyka, M. (2013). Tendencje w zużyciu nawozów mineralnych w Polsce na tle krajów Unii Europejskiej (Trends in consumption of mineral fertilizers in Poland against the background of the European Union). Roczniki Naukowe SERiA, 15(3), 237-241.

Piwowar, A. (2012). Charakterystyka przemysłu nawozowego w Polsce (Characteristic of fertilizer industry in Poland). Przemyst Chemiczny, 91(11), 2085-2089.

Piwowar, A. (2018). Chemiczna ochrona roślin we współczesnym rolnictwie w perspektywie ekonomicznej i ekologicznej - korzyści, koszty oraz preferencje (Chemical plant protection in the modern agriculture in economic and ecological perspectives - benefits, costs and preferences). Wyd. Uniwersytetu Ekonomicznego we Wrocławiu, Wrocław.

Schütte, G., Eckerstorfer, M., Valentina, R., Reichenbecher, W., Restrepo-Vassalli, S., Ruohonen-Lehto, M., Wuest Saucy, A.G., Mertens, M. (2017). Herbicide resistance and biodiversity: agronomic and environmental aspects of genetically modified herbicide-resistant plants. Environmental Sciences Europe, 29(1), 5. DOI 10.1186/ s12302-016-0100-y.

Środki produkcji w rolnictwie w roku gospodarczym 2015/16 (Means of production in agriculture in the 2015/2016 farming year). GUS, Warszawa 2017.

Tarnowska, A. (2016). Środki obrotowe a wielkość produkcji wybranych ziemiopłodów w dolnośląskich gospodarstwach rolnych na tle kraju w latach 1999-2014 (Current assets and size of production of selected crops in Dolnośląskie Voivodeship in 1999-2014). Optimum. Studia Ekonomiczne, 4(82), 167-184.

Urban, S. (2007). Zużycie nawozów mineralnych i środków ochrony roślin w aspekcie wymagań rolnictwa zrównoważonego (Mineral fertilizers and agrochemicals usage from the aspect of sustainable agriculture standards). Folia Univesutatis Agriculturae Stetinensis, Oeconomica 254(47), 333-340.

Vasic, V., Orlovic, S., Pap, P., Kovacevic, B., Drekic, M., Pajnik, L.P., Galic, Z. (2015). Application of preemergence herbicides in poplar nursery production. Journal of Forestry Research, 26(1), 143-151.

Zalewski, A. (2009). Sytuacja na rynku nawozów mineralnych w 2008 r. (Situation on the Market of Mineral Fertilizers in 2008). Journal of Agribusiness and Rural Development, 2(12), 279-286.

Zalewski, A. (2016). Światowy rynek nawozów mineralnych (Global fertilizers market) In: Rynek środków produkcji dla rolnictwa. Analizy Rynkowe 2016, no. 43, 15.

\section{For citation:}

Piwowar A. (2018). The Consumption of Mineral Fertilizers and Herbicides in Poland Against the Background of the European Union. Problems of World Agriculture, 18(1), 194-202;

DOI: $10.22630 /$ PRS.2018.18.1.18 